\title{
KEDUDUKAN HUKUM PERJANJIAN KAWIN YANG DIBUAT SETELAH PERKAWINAN DILANGSUNGKAN
}

\author{
Mohammad Zamroni ${ }^{1}$; Andika Persada Putra ${ }^{2}$ \\ ${ }^{1}$ Dosen Magister Hukum, Fakultas Hukum Universitas Hang Tuah \\ Jl. Arief Rachman Hakim No. 150 Surabaya \\ Email: zamroni@hangtuah.ac.id \\ ${ }^{2}$ Dosen Magister Hukum, Fakultas Hukum Universitas Hang Tuah \\ J1. Arief Rachman Hakim No. 150 Surabaya \\ Email: apersada.putera@gmail.com
}

\begin{abstract}
The Prenuptial agreement is generally made by prospective brides before or at the time of marriage, with consideration, among others, because the amount of brides' wealth is unbalanced, for example one party has more wealth than the other. But in its development, the marriage agreement is not only needed when the bride and groom will get married, but also when they become a husband and wife. With various reasons and interests, the husband and wife submit an application to the court to get an court decision. Based on the court decision, the husband and wife make a marriage agreement. This research aims to study the legal status of the marriage agreement made by husband and wife after marriage. The result of the research is that the legal position of the marriage agreement made after the marriage takes place is bound by the provisions of Article 29 of the Marriage Law, which is illegal and not binding, unless based on a court ruling.
\end{abstract}

Keywords: prenuptial agreement, community of property, marriage.

\begin{abstract}
Abstrak
Perjanjian kawin yang berisi penyimpangan terhadap persatuan harta kekayaan pada umumnya dibuat oleh calon mempelai sebelum atau pada saat melaksanakan perkawinan, dengan pertimbangan antara lain karena jumlah kekayaan calon mempelai yang tidak berimbang, misalnya salah satu calon mempelai memiliki harta lebih besar daripada calon satunya. Namun dalam perkembangannya, perjanjian kawin tidak hanya diperlukan ketika calon mempelai hendak melangsungkan perkawinan, tetapi juga ketika sudah menjadi pasangan suami istri. Dengan berbagai alasan dan kepentingan, pasangan suami istri mengajukan permohonan kepada pengadilan untuk mendapatkan penetapan. Berdasarkan pada penetapan pengadilan tersebut, selanjutnya pasangan suami istri membuat perjanjian kawin. Penelitian ini bertujuan untuk mengkaji kedudukan hukum perjanjian kawin yang dibuat oleh pasangan suami istri setelah perkawinan dilangsungkan. Hasil penelitian adalah
\end{abstract}


bahwa kedudukan hukum perjanjian kawin yang dibuat setelah perkawinan berlangsung terikat pada ketentuan Pasal 29 UU Perkawinan, yaitu tidak sah dan tidak mengikat, kecuali didasarkan pada penetapan pengadilan.

Kata kunci: Perjanjian Kawin, Harta Bersama, Perkawinan.

\section{PENDAHULUAN}

Perkawinan merupakan suatu peristiwa penting yang tidak sekedar menyatukan seorang laki-laki dan seorang perempuan hidup bersama sebagai pasangan suami istri. Lebih dari itu, perkawinan dapat membawa akibat hukum terhadap harta kekayaan mereka. Mengingat akibat hukum yang ditimbulkan tersebut, maka tidak jarang calon mempelai sebelum melangsungkan perkawinan membuat perjanjian kawin untuk mengatur harta kekayaan mereka. Secara normatif, ketentuan mengenai perjanjian kawin telah diatur secara tegas pada Pasal 29 Undang-Undang No. 1 Tahun 1974 tentang Perkawinan (selanjutnya disebut UU Perkawinan).

Pada umumnya maksud dan tujuan membuat perjanjian kawin adalah untuk mengatur akibat hukum dari terjadinya suatu perkawinan, yaitu mengenai harta kekayaan agar tidak terjadi persatuan harta kekayaan perkawinan diantara suami istri selama perkawinan. Perjanjian kawin yang berisi penyimpangan terhadap persatuan harta kekayaan tersebut dibuat oleh calon mempelai sebelum atau pada saat melaksanakan perkawinan, dengan pertimbangan antara lain karena jumlah kekayaan calon mempelai yang tidak berimbang, misalnya salah satu calon mempelai kaya raya, sementara calon mempelai yang satunya tidak banyak memiliki harta. ${ }^{1}$ Namun dalam perkembangannya, perjanjian kawin tidak hanya dibutuhkan ketika calon mempelai hendak melangsungkan perkawinan, tetapi juga ketika mereka sudah menjadi pasangan suami istri.

Banyak peristiwa di masyarakat yang mendorong pasangan suami istri perlu membuat perjanjian kawin setelah perkawinan berlangsung. Misalnya salah satu pasangan (suami/istri) bekerja dalam jabatannya sebagai direksi suatu Perseroan Terbatas, hal mana ia harus bertanggung jawab penuh atas kerugian Perseroan Terbatas sampai harta kekayaan pribadi jika ia bersalah atau lalai menjalakan tugasnya. Hal ini tentu akan berpengaruh

${ }^{1}$ Lihat Mochamad Djais, Hukum Harta Kekayaan Dalam Perkawinan, Fakultas Hukum Universitas Diponegoro, Semarang, 2008, hlm. 101. 
terhadap harta bersama, padahal yang bertanggung jawab seharusnya hanyalah salah satu pasangan (suami/istri), bukan kedua-duanya. Tetapi karena harta kekayaan pasangan suami istri menjadi harta bersama, maka keseluruhan harta ikut menanggung kerugian yang dilakukan oleh salah satu pasangan suami istri. Situasi berbeda jika pasangan suami istri telah memiliki perjanjian kawin, karena hanya akan berpengaruh terhadap harta salah satu pasangan (suami/istri).

Pada dasarnya perjanjian kawin telah diatur secara tegas pada Pasal 29 UU Perkawinan, termasuk diatur mengenai waktu membuat perjanjian kawin, yaitu hanya dapat dibuat sebelum atau pada saat perkawinan dilangsungkan. Sehingga tidak ada peluang untuk membuat perjanjian kawin setelah perkawinan dilangsungkan. Tetapi dalam praktik, banyak pasangan suami istri membuat perjanjian kawin setelah perkawinan dilangsungkan. Dengan berbagai alasan dan kepentingan, pasangan suami istri mengajukan permohonan kepada pengadilan untuk mendapatkan penetapan. Hal ini dapat dilihat pada penetapan Pengadilan Negeri Jakarta Timur No. 207/Pdt.P/2005/PN.Jkt.Tmr. yang diajukan oleh pasangan suami istri Syam Lal Uttam dan Kavita Uttam, dan Penetapan Pengadilan Negeri Jakarta Timur No. 459/Pdt.P/2007/PN.Jkt.Tmr. yang diajukan oleh pasangan suami istri Dubagunta Ramesh dan Selvia Setiawan.

\section{RUMUSAN MASALAH}

Beranjak dari eksplikasi di atas, maka penelitian ini difokuskan untuk mengkaji kedudukan hukum perjanjian kawin yang dibuat oleh pasangan suami istri setelah perkawinan dilangsungkan.

\section{TUJUAN PENELITIAN}

Adapun tujuan dari penelitian adalah untuk menemukan kedudukan hukum perjanjian kawin yang dibuat oleh pasangan suami istri setelah perkawinan dilangsungkan.

\section{METODE PENELITIAN}

Ilmu hukum akan mempunyai kewibawaan dan kekuatannya apabila bersifat integral dalam aspek ontologis, epistemologis, dan aksiologis. Oleh sebba itu diperlukan metode-metode dalam menemukan hukum. ${ }^{2}$ Penelitian ini merupakan penelitian hukum yuridis normatif. Pendekatan yang digunakan adalah pendekatan perundang-undangan (statute approach) dan pendekatan konseptual (conceptual approach). Penentuan bahan hukum (legal materials)

2 Yati Nurhayati, Perdebatan Antara Metode Normatif dengan Metode Empirik Dalam Penelitian Ilmu Hukum Ditinjau Dari Karakter, Fungsi dan Tujuan Ilmu Hukum, Jurnal Hukum Al Adl, Volume V Nomor 10, Juli-Desember 2013, hlm. 14. 
dan analisis kritis (critical analysis) terhadap bahan hukum dilakukan melalui oleh pikir yang bersifat penelusuran (explorative), pengkajian mendalam (inquiry) dan penafsiran (interprestation). ${ }^{3}$

\section{PEMBAHASAN}

\section{Perjanjian Kawin Menurut Burgerlijk}

\section{Wetboek}

Ketentuan perjanjian kawin diatur cukup lengkap dalam Burgerlijk Wetboek (selanjutnya disebut BW). Selain diatur dalam Bab ketujuh yang mengatur tentang Perjanjian Perkawinan, juga diatur pada Bab kedelapan yang mengatur tentang Persatuan atau Perjanjian Perkawinan dalam Perkawinan untuk Kedua Kali atau Selanjutnya. Secara umum hal-hal yang diatur dalam Bab ketujuh dan Bab kedelapan mulai Pasal 139 sampai dengan Pasal 185 adalah sebagai berikut :

1. Perjanjian kawin dapat menyimpangi peraturan perundang-undangan mengenai persatuan harta kekayaan, asalkan tidak melanggar kesusilaan, ketertiban umum, dan ketentuan perjanjian kawin yang diatur dalam BW.

${ }^{3}$ Lihat J.J Bruggink, Rechsreflecties, alih bahasa Arief Sidharta, Citra Aditya Bakti, Bandung, 1996, hlm.10.
2. Perjanjian kawin tidak boleh memperjanjikan bahwa perkawinan akan diatur oleh undang-undang luar negeri, atau adat kebiasaan dan peraturan-peraturan perundangundangan yang dahulu pernah berlaku di Indonesia.

3. Perjanjian kawin harus dibuat dengan akta notaris sebelum perkawinan berlangsung.

4. Perjanjian kawin berlaku sejak saat perkawinan dilangsungkan.

5. Atas kesepakatan kedua calon mempelai, perjanjian kawin dapat diubah sebelum perkawinan dilangsungkan.

6. Perjanjian kawin tidak dapat diubah setelah perkawinan dilangsungkan.

7. Perjanjian kawin berlaku mengikat pihak ketiga setelah didaftarkan di kepaniteraan Pengadilan Negeri.

8. Perjanjian kawin tidak berlaku apabila tidak diikuti dengan perkawinan.

Sebagaimana dirumuskan pada Pasal 139 BW, kedua calon mempelai diberikan peluang untuk membuat perjanjian kawin dengan menyimpangi peraturan undang-undang sekitar persatuan harta kekayaan. BW menyebut 
penyimpangan ini sebagai hak. Menurut Moch. Isnaeni ${ }^{4}$, ketentuan Perjanjian Kawin dalam BW merupakan regelend recht, yaitu ketentuan undang-undang yang bersifat mengatur, sehingga dapat disimpangi. Ia berpendapat bahwa pada hakekatnya sebuah perjanjian kawin dibuat oleh calon mempelai dalam rangka menyimpangi aturan undang-undang yang menangani harta perkawinan yang telah dibuat oleh penguasa. Menurutnya, mengesampingkan suatu pasal dalam sebuah undang-undang bukanlah tabu, sepanjang aturan yang disimpangi tersebut berposisi sebagai regelend recht, dengan syarat bahwa hal itu didasarkan pada kesepakatan para pihak.

Namun demikian, meskipun kedua calon mempelai diberikan hak untuk menyimpangi peraturan undang-undang, BW melarang kedua calon mempalai memperjanjikan bahwa ikatan perkawinan mereka akan diatur oleh undang-undang luar negeri, atau adat kebiasaan dan peraturan-peraturan perundang-undangan yang dahulu pernah berlaku di Indonesia. Hal ini ditegaskan pada Pasal 143 BW.

Selanjutnya mengenai bentuk perjanjian, BW mensyaratkan bahwa perjanjian kawin harus dibuat dengan akta

4 Moch. Isnaeni, Hukum Perkawinan Indonesia, Revka Petra Media, Surabaya, 2016, hlm. 172. notaris. Sedangkan waktu pembuatan perjanjian kawin ditentukan harus dibuat sebelum perkawinan berlangsung. Hal ini dirumuskan secara tegas pada Pasal 147 BW, dengan ancaman kebatalan apabila perjanjian kawin tidak dibuat dengan akta notaris sebelum perkawinan berlangsung. Apabila ditafsirkan secara a contratio, maka pada dasarnya BW tidak memberikan peluang untuk membuat perjanjian kawin setelah perkawinan dilangsungkan. Meskipun mengenai hal ini tidak disebutkan secara tegas dalam BW.

Mengenai obyek perjanjian kawin, BW tidak memberikan pembatasan apa saja yang termasuk atau tidak termasuk obyek perjanjian kawin, sehingga perjanjian kawin meliputi semua hal, asalkan berupa suatu hal tertentu sebagaimana disyaratkan dalam Pasal 1320 BW. Sedangkan terhadap perubahan perjanjian kawin, Pasal 149 BW secara tegas menyatakan bahwa perjanjian kawin tidak dapat diubah setelah perkawinan berlangsung. Perubahan perjanjian kawin hanya dimungkinkan dilakukan sebelum dilangsungkannya perkawinan, dengan syarat perubahan yang dilakukan disepakati oleh kedua calon mempelai, dan dibuat dalam bentuk yang sama seperti akta perjanjian yang dibuat sebelumnya.

Perjanjian kawin berlaku mengikat kedua belah pihak (suami istri) sejak saat 
perkawinan dilangsungkan. Hal ini ditegaskan pada Pasal 147 BW. Sedangkan terhadap pihak ketiga, Pasal 152 BW menyebutkan bahwa perjanjian kawin berlaku mengikat pihak ketiga sejak didaftarkan di kepaniteraan Pengadilan Negeri, tempat di mana perkawinan dilangsungkan. Atau jika perkawinan dilangsungkan di luar negeri, pendaftaran perjanjian kawin dilakukan di kepaniteraan Pengadilan Negeri tempat di mana akta perkawinan dicatatkan. Selain mengatur hal-hal yang sifatnya umum di atas, BW juga mengatur secara terperinci hal-hal yang berkaitan dengan hibah yang diberikan dalam perjanjian kawin dan persatuan harta kekayaan.

\section{Perjanjian Kawin Menurut Undang-} Undang No. 1 Tahun 1974

Apabila diperbandingkan dengan ketentuan perjanjian kawin yang dirumuskan dalam BW, ketentuan perjanjian kawin dalam UU No. 1 Tahun 1974 tentang Perkawinan (selanjutnya disebut UU Perkawinan) dirumuskan lebih ringkas. Bahkan UU Perkawinan hanya mengatur mengenai perjanjian kawin dalam satu pasal saja. Menurut Moch. Isnaeni, perbandingan ini sangat mencolok. UU Perkawinan yang hanya mengatur perjanjian kawin dalam satu pasal terkesan memberikan kesempatan kepada calon mempelai untuk mengatur sendiri harta kawinnya dengan keleluasaan yang amat longgar, meskipun dengan batas-batas tidak boleh melangar hukum, kesusilaan, dan agama. ${ }^{5}$

Ketentuan perjanjian kawin dalam UU Perkawinan diatur pada Pasal 29, yang menyebutkan :

(1) Pada waktu atau sebelum perkawinan dilangsungkan, kedua pihak atas perjanjian bersama dapat mengadakan perjanjian tertulis yang disahkan oleh Pegawai pencatat perkawinan, setelah mana isinya berlaku juga terhadap pihak ketiga sepanjang pihak ketiga tersangkut.

(2) Perjanjian tersebut tidak dapat disahkan bilamana melanggar batas-batas hukum, agama dan kesusilaan.

(3) Perjanjian tersebut berlaku sejak perkawinan dilangsungkan.

(4) Selama perkawinan berlangsung perjanjian tersebut tidak dapat diubah, kecuali bila dari kedua belah pihak ada perjanjian untuk mengubah dan perubahan tidak merugikan pihak ketiga.

Ketentuan Pasal 29 ayat (1) menegaskan bahwa perjanjian kawin hanya dapat dibuat pada saat perkawinan dilangsungkan, atau sebelum perkawinan dilangsungkan. Sehingga tidak ada peluang untuk membuat perjanjian kawin setelah perkawinan resmi dilangsungkan.

\footnotetext{
${ }^{5}$ Ibid., hlm. 164
} 
Perjanjian kawin seperti ini lazim disebut sebagai pre-nuptial agreement (disingkat pre-nupt), atau pre-marital agreement. Selain itu, perjanjian kawin juga harus dibuat secara tertulis, tidak boleh hanya dilakukan secara lisan. Hal ini karena perjanjian kawin dapat membawa akibat hukum terhadap pihak ketiga, apabila pihak ketiga dimaksud tersangkut dalam perjanjian kawin yang dibuat calon mempelai.

Mengenai akibat hukum terhadap pihak ketiga, Pasal 29 ayat (1) menegaskan bahwa perjanjian kawin berlaku mengikat pihak ketiga setelah disahkan oleh Pegawai pencatat perkawinan. Pengesahan ini dilakukan dengan cara mencatat perjanjian kawin dalam akta perkawinan, sebagaimana diatur dalam Pasal 12 huruf $h$ Peraturan Pemerintah No. 9 Tahun 1975 tentang Pelaksanaan Undang-Undang No. 1 Tahun 1974 tentang Perkawinan. Selain daripada itu, perjanjian kawin dapat mengikat pihak ketiga sepanjang pihak ketiga tersangkut.

Selanjutnya Pasal 29 ayat (2) menegaskan bahwa perjanjian kawin tidak dapat disahkan apabila melanggar batasbatas hukum, agama dan kesusilaan. Ketentuan ini mencerminkan eksistensi asas kebebasan berkontrak dalam perjanjian kawin, dengan memberikan kebebasan kepada calon mempelai untuk memperjanjikan hal-hal apa saja dalam perjanjian kawin yang dibuat, sepanjang tidak melanggar ketentuan-ketentuan hukum, aturan-aturan dalam agama, dan norma-norma kesuliaan yang ada di masyarakat.

Ketentuan Pasal 29 ayat (3) menegaskan mengenai waktu berlakunya perjanjian kawin, yaitu sejak perkawinan resmi dilangsungkan. Sedangkan pada ayat (4) menegaskan mengenai perubahan perjanjian kawin selama perkawinan berlangsung. Berbeda dengan BW yang tidak membolehkan mengubah perjanjian kawin setelah perkawinan dilangsungkan, UU Perkawinan memberikan peluang untuk mengubah perjanjian kawin, asalkan kedua belah pihak (suami istri) menyepakati perubahan tersebut, dan perubahan yang dilakukan tidak merugikan pihak ketiga.

Mengenai obyek perjanjian kawin, UU Perkawinan juga memberikan keleluasaan kepada calon mempelai untuk memperjanjikan obyek apa saja. Pembatasan obyek perjanjian kawin hanya terhadap ta'lik talak. ${ }^{6}$ Hal ini berbeda dengan Kompilasi Hukum Islam yang memasukkan ta'lik talak sebagai obyek perjanjian kawin. Sebagaimana diketahui,

${ }^{6}$ Lihat penjelasan Pasal 29 UU No. 1 Tahun 1974, yang menyebutkan bahwa yang dimaksud 'perjanjian' dalam pasal ini tidak termasuk ta'lik talak. 
ta'lik talak lazim dilakukan oleh orang Indonesia yang beragama Islam. Ta'lik talak adalah talak yang digantungkan, merupakan suatu janji suami terhadap istri sesaat setelah melakukan akad nikah. Menurut Kompilasi Hukum Islam, ta'lik talak merupakan salah satu alasan yang dapat digunakan oleh istri untuk mengajukan perceraian, yaitu apabila suami melanggar ta'lik talak.

Tidak adanya ketentuan mengenai obyek perjanjian kawin juga mengindikasikan bahwa lembaga perjanjian kawin dalam UU Perkawinan menganut asas kebebasan berkontrak. Mengenai hal ini Moch. Isnaeni berpendapat bahwa dalam kontek membuat perjanjian kawin, pembentuk UU Perkawinan berani menyematkan asas kebebasan berkontrak dalam ruang hukum keluarga yang umumnya ketentuanketentuannya didominasi oleh $d$ wingend recht. Dengan menonjolkan asas kebebasan berkontrak, maka sangat wajar apabila ketentuan perjanjian kawin dirasa cukup diatur dengan satu pasal saja. Karena isi perjanjian kawin diserahkan sepenuhnya kepada calon mempelai untuk mengatur sendiri, asalkan tidak bertentangan dengan hukum, agama, dan kesusilaan. $^{7}$

\footnotetext{
${ }^{7}$ Moch. Isnaeni, Op.cit., hlm. 164-165.
}

\section{Perjanjian Kawin Menurut Kompilasi}

Hukum Islam

Apabila mengacu pada Pasal 7 ayat (1) UU No. 12 Tahun 2011 tentang Pembentukan Peraturan PerundangUndangan, maka Kompilasi Hukum Islam bukanlah termasuk dalam jenis dan hierarki peraturan perundang-undangan. Namun demikian, berdasarkan Instruksi Presiden No. 1 Tahun 1991, Kompilasi Hukum Islam dinyatakan dapat dipergunakan sebagai pedoman oleh istansi pemerintah dan masyarakat dalam menyelesaikan masalah-masalah di bidang perkawinan, kewarisan dan perwakafan.

Menurut Bagir Manan, Instruksi Presiden tidak tergolong peraturan perundang-undangan. Namun demikian, Instruksi Presiden berisi ketentuan konkrit yang harus dilaksanakan atau tidak dilaksanakan oleh pejabat administrasi negara. ${ }^{8}$ Oleh karenanya Istruksi Presiden tersebut kemudian dikuatkan oleh Keputusan Menteri Agama No. 154 Tahun 1991 tentang Pelaksanaan Instruksi Presiden No. 1 Tahun 1991, yang dalam diktum kedua disebutkan bahwa seluruh lingkungan instansi Departemen Agama dan instansi pemerintah lainnya yang terkait, dalam menyelesaikan masalah-

8 Bagir Manan, Teori dan Politik Konstitusi, Faultas Hukum UII, Yogyakarta, 2003, hlm. 211. 
masalah di bidang hukum perkawinan, kewarisan dan perwakafan sedapat mungkin menerapkan Kompilasi Hukum Islam, disamping peraturan perundangundangan lainnya.

Di dalam praktik peradilan agama, Kompilasi Hukum Islam lazim diterapkan oleh hakim dalam menyelesaikan permasalahan yang dihadapkan kepadanya. Hal ini dilatarbelakangi oleh Keputusan Bersama Ketua Mahkamah Agung dan Menteri Agama tanggal 21 Maret 1985 No. 07/KMA/1985 dan No. 25 Tahun 1985 tentang penunjukan pelaksanaan proyek pembangunan hukum Islam melalui yurisprudensi, atau lebih dikenal dengan proyek Kompilasi Hukum Islam. ${ }^{9}$

Berkaitan dengan ketentuan perjanjian kawin, meskipun tidak selengkap sebagaimana yang diatur dalam BW, ketentuan perjanjian kawin dalam Kompilasi Hukum Islam diatur lebih terperinci dibandingkan dengan ketentuan perjanjian kawin dalam UU Perkawinan. Perjanjian kawin dalam Kompilasi Hukum Islam diatur dalam Buku I Hukum Perkawinan, pada Bab VII tentang Perjanjian Perkawinan, mulai Pasal 45 sampai dengan Pasal 52. Secara umum ketentuan perjanjian kawin yang diatur

${ }^{9}$ Lihat Abdurrahman, Kompilasi Hukum Islam di Indonesia, Akademika Pressindo, Jakarta, 1995, hlm. 15. dalam Kompilasi Hukum Islam adalah sebagai berikut :

1. Kedua calon mempelai dapat membuat perjanjian kawin dalam bentuk ta'lik talak dan perjanjian lainnya yang tidak bertentangan dengan hukum Islam.

2. Pada waktu atau sebelum perkawinan dilangsungkan, kedua calon mempelai dapat membuat perjanjian kawin secara tertulis yang disahkan pegawai pencatat nikah, mengenai kedudukan harta dalam perkawinan.

3. Perjanjian kawin mengenai harta, mengikat kepada para pihak dan kepada pihak ketiga terhitung sejak perkawinan dilangsungkan di hadapan pegawai pencatat nikah.

4. Perjanjian kawin mengenai harta dapat dicabut atas persetujuan kedua belah pihak (suami-isteri).

5. Pencabutan perjanjian kawin mengenai harta harus didaftarkan di kantor pegawai pencatat nikah, dan diumumkan dalam suatu surat kabar setempat. Apabila dalam tenggang waktu enam bulan sejak didaftrkan tidak diumumkan di surat kabar, maka pendaftaran dianggap gugur dan tidak mengikat pihak ketiga.

6. Pencabutan perjanjian kawin mengenai harta mengikat pihak ketiga setelah diumumkan dalam suatu surat kabar.

7. Pencabutan perjanjian kawin mengenai harta tidak boleh merugikan perjanjian yang telah dibuat dengan pihak ketiga. 
Berbeda dengan UU Perkawinan yang menegaskan bahwa perjanjian kawin tidak termasuk ta'lik talak, Kompilasi Hukum Islam justru membolehkan perjanjian kawin dibuat dalam bentuk ta'lik talak. Kompilasi Hukum Islam bahkan memberikan keleluasaan kepada calon mempelai untuk membuat perjanjian kawin dalam bentuk apa saja, asalkan tidak bertentangan dengan hukum Islam. $^{10}$ Mengenai hal ini, boleh jadi pembentuk Kompilasi Hukum Islam menganggap tidak perlu menegaskan soal batasan tidak boleh melanggar peraturan perundangundangan, ketertiban umum, dan juga kesusilaan. Karena pelanggaran terhadap hal-hal tersebut pada dasarnya juga bertentangan dengan hukum Islam. Sehingga cukuplah dibuat pembatasan sepanjang tidak bertentangan dengan hukum Islam.

Mengenai waktu pembuatan perjanjian kawin, Kompilasi Hukum Islam menganut norma yang ada dalam UU Perkawinan, yaitu dibuat sebelum atau pada saat perkawinan dilangsungkan. Demikian halnya terkait keabsahan perjanjian kawin, sama dengan yang ditentukan dalam UU Perkawinan, perjanjian kawin dalam Kompilasi Hukum Islam juga ditentukan harus dibuat secara

10 Lihat ketentuan Pasal 45 Kompilasi Hukum Islam. tertulis dan disahkan oleh Pegawai Pencatat Nikah. ${ }^{11}$ Sedangkan akibat hukum perjanjian kawin terhadap pihak ketiga, sebagaimana ditegaskan pada Pasal 50 Kompilasi Hukum Islam, bahwa perjanjian kawin mengikat pada pihak ketiga terhitung sejak tanggal dilangsungkan perkawinan di hadapan Pegawai pencatat nikah.

Kompilasi Hukum Islam memang tidak mengatur mengenai perubahan perjanjian kawin, akan tetapi menambahkan ketentuan mengenai pencabutan perjanjian kawin. Pasal 50 ayat (2) Kompilasi Hukum Islam menyebutkan, bahwa perjanjian kawin mengenai harta dapat dicabut atas persetujuan bersama suami istri dan wajib mendaftarkannya di kantor pegawai pencatat nikah tempat perkawinan dilangsungkan. Penyebutan "suami istri" dalam rumusan Pasal 50 ayat (2) menunjukkan bahwa pencabutan perjanjian kawin dapat dilakukan setelah perkawinan berlangsung, yaitu setelah kedua mempelai sah menjadi suami istri.

Pada Pasal 50 ayat (3) ditegaskan bahwa pencabutan perjanjian kawin berlaku mengikat terhadap suami istri sejak pendaftaran pencabutan dilakukan. Sedangkan terhadap pihak ketiga, pencabutan perjanjian kawin berlaku

11 Lihat ketentuan Pasal 47 Kompilasi Hukum Islam. 
mengikat sejak pendaftaran pencabutan kawin diumumkan oleh suami istri dalam suatu surat kabar. Dengan kata lain, pencabutan perjanjian kawin tidak mengikat pihak ketiga apabila tidak diumumkan di surat kabar. Hal ini juga dipertegas pada Pasal 50 ayat (4), yang menyebutkan bahwa apabila dalam tempo enam bulan sejak didaftarkan tidak diumumkan di surat kabar, maka pendaftaran pencabutan perjanjian kawin mengenai harta dengan sendirinya gugur dan tidak mengikat kepada pihak ketiga. Selain daripada itu, pencabutan perjanjian kawin mengenai harta tidak boleh merugikan perjanjian yang telah dibuat sebelumnya dengan pihak ketiga. ${ }^{12}$ Penyebutan perjanjian kawin 'mengenai harta' dalam rumusan Kompilasi Hukum Islam dimaksudkan untuk membedakan perjanjian kawin yang lain di luar perjanjian ta'lik talak.

\section{Batas-batas Perjanjian Kawin}

Pada dasarnya, baik BW, UU Perkawinan, maupun Kompilasi Hukum Islam mencerminkan eksistensi asas kebebasan berkontrak. Kebebasan berkontrak adalah kebebasan para pihak yang terlibat dalam suatu perjanjian, untuk dapat menyusun dan menyetujui klausul-

12 Lihat ketentuan Pasal 50 ayat (5) Kompilasi Hukum Islam. klausul dari perjanjian tersebut, tanpa campur tangan pihak lain. ${ }^{13}$ Setiap orang bebas untuk menentukan dengan siapa ia akan mengikatkan dirinya, bebas untuk menentukan isi dan bentuk perjanjian, dan bebas untuk membuat pilihan hukum. ${ }^{14} \mathrm{Di}$ dalam kebebasan berkontrak terkandung suatu pandangan bahwa orang bebas untuk melakukan atau tidak melakukan perjanjian, bebas dengan siapa ia mengadakan perjanjian, bebas tentang apa yang diperjanjikan dan bebas untuk menetapkan syarat-syarat perjanjian. ${ }^{15}$

Nieuwenhuis ${ }^{16}$ membagi kebebasan berkontrak dalam dua macam, yaitu menurut bentuk dan menurut isi. Kebebasan menurut bentuk, ditandai dengan sifatnya yang konsensual. Artinya, persesuaian kehendak (consensus) tidak hanya perlu tetapi juga sudah cukup. Tidak

${ }^{13}$ Lihat P.S. Atiyah, The Rise and Fall of Freedom of Contract, Clarendon Press, Oxford, 1979, p. 703-712.

14 Taufik El Rahman et.al., "Asas Kebebasan Berkontrak dan Asas Kepribadian Dalam Kontrak-kontrak Outsourcing”, Mimbar Hukum, Vol. 23 No. 3, Oktober 2011, hlm. 585.

15 Peter Mahmud Marzuki, "Batas-Batas Kebebasan Berkontrak", Yuridika, Vol. 18 No. 3, Mei 2003, h. 219. Lihat juga A.H. Angelo and E.P. Ellinger, "Unconscionable Contract: A Comparative Study of the Approaches in England, France, Germany, and the United States", Loyola of Los Angeles International \& Comparative Law Review, Vol. 14, January 1992, p. 455, yang menulis, the parties to a transaction are free, or entitled, to agree on, or to choose, any lawful terms.

16 J.H. Nieuwenhuis, Pokok-Pokok Hukum Perikatan, Terjemahan Djasadin Saragih, Universitas Airlangga, Surabaya, 1985, hlm. 83. 
disyaratkan untuk memerhatikan formasiltas-formalitas pada penutupan kontrak. Tetapi apabila para pihak menuangkan hubungan hukum mereka dalam sesuatu yang tertulis, maka ini hanya memudahkan pembuktian. Sedangkan mengenai kebebasan menurut isi, mengandung pengertian bahwa para pihak dapat menentukan isi hubunganhubungan obligatoir mereka sesuai dengan yang mereka kehendaki.

Namun demikian, kebebasan berkontrak bukanlah tanpa batas, untuk melindungi warga masyarakat, negara seringkali membatasi kebebasan berkontrak yang dituangkan dalam peraturan perundang-undangan. Menurut Nieuwenhuis, pembatasan kebebasan berkontrak tidak hanya mengenai isi akan tetapi juga mengenai bentuknya. Adanya kontrak-kontrak formal dan kontrakkontrak riil merupakan pembatasan terhadap asas bebas bentuk. Perjanjian hibah (schenking) adalah salah satu contoh kontrak formal. Akta notaris merupakan syarat keabsahan (geldigheids vereiste), sehingga timbulnya keterikatan kontraktual adalah ketika perjanjian hibah telah dituangkan dalam bentuk akta notariil. ${ }^{17}$

Demikian halnya dengan perjanjian kawin, peraturan perundang-undangan

\footnotetext{
${ }^{17}$ Ibid., hlm. 83-86.
}

memberikan batasan baik mengenai bentuk, isi, waktu, maupun perubahannya.

\section{Bentuk Perjanjian Kawin}

Secara umum, bentuk perjanjian kawin sudah diatur dalam peraturan perundang-undangan, sehingga perjanjian kawin harus dibuat dalam bentuk seperti yang disyaratkan oleh peraturan perundang-undangan. Baik dalam BW maupun dalam UU Perkawinan, bentuk perjanjian kawin sama-sama disyaratkan harus tertulis, demikian halnya dalam Kompilasi Hukum Islam. Perbedaannya hanyalah pada kualitas pembuktian. Ada yang mensyaratkan harus dibuat dengan akta notaris, ada yang tidak memberikan penjelasan.

Di dalam BW, bentuk perjanjian kawin diatur pada Pasal 147 BW, yang menyebutkan bahwa :

"Atas ancaman kebatalan, setiap perjanjian perkawinan harus dibuat dengan akta notaris sebelum perkawinan berlangsung."

Berdasarkan ketentuan ini, maka perjanjian kawin disyaratkan harus dibuat dalam bentuk akta notariil, jadi tidak cukup hanya bentuk tertulis. Karena bilamana perjanjian kawin tidak dibuat dalam bentuk akta notariil, maka perjanjian kawin terancam dapat dibatalkan.

Menurut Tan Thong Kie, syarat pada Pasal 147 BW dimaksudkan agar perjanjian kawin mempunyai kekuatan 
pembuktian yang kuat. Selain itu juga dapat memberikan kepastian hukum tentang hak dan kewajiban suami istri atas harta benda mereka, mengingat perjanjian kawin mempunyai akibat yang luas. Untuk membuat perjanjian kawin dibutuhkan seseorang yang benar-benar menguasai hukum harta perkawinan dan dapat merumuskan semua syarat dengan teliti. Kapasitas ini ada pada diri notaris. Hal ini juga terkait dengan aturan bahwa perjanjian kawin tidak dapat diubah selama perkawinan berlangsung. Sehingga jika terjadi suatu kekeliruan dalam merumuskan syarat dalam perjanjian kawin, maka tidak dapat diperbaiki lagi sepanjang perkawinan. ${ }^{18}$

Sedangkan dalam UU Perkawinan, bentuk perjanjian diatur pada Pasal 29 ayat (1), yang menyebutkan bahwa :

"Pada waktu atau sebelum perkawinan dilangsungkan, kedua belah pihak atas perjanjian bersama dapat mengadakan perjanjian tertulis yang disahkan oleh pegawai pencatat perkawinan setelah mana isinya berlaku juga terhadap pihak ketiga sepanjang pihak ketiga tersangkut."

Ketentuan dalam UU Perkawinan ini memang tidak secara tegas menyebutkan mengenai bentuk spesifik dari perjanjian kawin, apakah harus dalam

${ }^{18}$ Tan Thong Kie, Studi Notariat SerbaSerbi Praktek Notaris, Ichtiar Baru van Hoeve, Jakarta, 2000, hlm. 77. bentuk akta notraiil ataukah cukup dengan akta di bawah tangan. Perjanjian kawin hanya disyaratkan harus dibuat secara tertulis dan disahkan oleh pegawai pencatat perkawinan.

Eksistensi pegawai pencatat perkawinan selaku perwakilan pemerintah yang mengesahkan perjanjian, boleh jadi dianggap cukup oleh pembentuk UU Perkawinan untuk menguatkan pembuktian, sehingga perjanjian kawin tidak perlu harus dibuat dalam bentuk akta notariil. Apalagi perjanjian kawin juga dimuat dalam akta perkawinan, sebagaimana diatur pada Pasal 12 huruf h Peraturan Pemerintah No. 9 Tahun 1975 tentang Pelaksanaan Undang-Undang No. 1 Tahun 1974 tentang Perkawinan.

Sementara dalam Kompilasi Hukum Islam, perjanjian kawin diatur pada pada Pasal 47 ayat (1), yang menyebutkan bahwa:

"Pada waktu atau sebelum perkawinan dilangsungkan, kedua calon mempelai dapat membuat perjanjian tertulis yang disahkan pegawai pencatat nikah mengenai kedudukan harta dalam perkawinan."

Rumusan ini redaksinya hampir sama dengan rumusan Pasal 29 ayat (1) UU Perkawinan. Perbedaannya hanyalah pada penambahan obyek perjanjian berupa kedudukan harta dalam perkawinan. Hal ini ditegaskan karena Kompilasi Hukum 
Islam memasukkan perjanjian ta'lik talak menjadi bagian dari perjanjian kawin. Sehingga harus dibedakan antara perjanjian ta'lik talak dan perjanjian kawin di luar ta'lik talak, yang lazimnya mengenai kedudukan harta dalam perkawinan. Namun demikian, sama dengan ketentuan dalam UU Perkawinan, Kompilasi Hukum Islam juga mensyaratkan perjanjian kawin harus dibuat dalam bentuk tertulis yang disahkan oleh pegawai pencatat nikah.

\section{Isi Perjanjian Kawin}

Pada dasarnya isi perjanjian kawin diserahkan sepenuhnya kepada calon mempelai untuk mengatur sendiri apa saja yang hendak diperjanjikan. Namun demikian ada batasan-batasan yang diberikan oleh undang-undang untuk tidak dilanggar. Di dalam BW, batas-batas yang tidak boleh dilanggar dalam membuat isi perjanjian kawin adalah sebagai berikut :

1. Tidak boleh bertentangan dengan kesusilaan atau ketertiban umum (Pasal 139 BW).

2. Tidak boleh mengurangi hak kekuasaan suami, atau hak kekuasaan orang tua, dan hakhak suami atau istri yang hidup terlama (Pasal 140 BW).

3. Tidak boleh mengatur atau melepaskan hak-hak atas harta peninggalan keluarga sedarah dalam garis ke bawah (Pasal $141 \mathrm{BW})$.
4. Tidak boleh memperjanjikan salah satu pihak, baik suami atau istri harus membayar utang lebih besar dari bagiannya atas keuntungan harta persatuan (Pasal 142 BW).

5. Tidak boleh memperjanjikan bahwa ikatan perkawinan akan diatur oleh peraturan perundang-undangan negara asing, atau peraturan yang dahulu pernah berlaku di Indonesia (Pasal 143 BW).

UU Perkawinan tidak memberikan batasan secara spesifik terhadap isi perjanjian kawin. Rumusan Pasal 29 ayat (2) UU Perkawinan hanya menyebutkan bahwa "Perjanjian tersebut tidak dapat disahkan bilamana melanggar batas-batas hukum, agama dan kesusilaan.” Rumusan ini sifatnya umum, sehingga normanya dapat melingkupi semua aturan-aturan hukum, norma-norma agama, dan tata susila yang ada dan hidup di masyarakat. Meskipun jika dikaji lebih jauh, sebenarnya norma agama juga sudah melingkupi norma kesusilaan. Karena norma kesusilaan merupakan bagian integral dari norma agama.

Sedangkan dalam Kompilasi Hukum Islam, batasan yang tidak boleh dilanggar dalam membuat isi perjanjian kawin adalah sebagai berikut :

1. Tidak boleh bertentangan dengan hukum Islam (Pasal 45 ayat 2) dan Pasal 47 ayat (2)). 
2. Tidak boleh menghilangkan kewajiban suami untuk memenuhi kebutuhan rumah tangga (Pasal 48 ayat (1)).

Tidak dimasukkannya larangan isi perjanjian kawin melanggar undangundang dan kesusilaan, bukan berarti bahwa isi perjanjian kawin boleh melanggar undang-undang dan kesusilaan. Karena pada hakekatnya hukum Islam sudah melarang setiap perbuatan yang sifatnya melanggar hukum, baik hukum yang dibuat oleh negara maupun hukum agama. Demikian halnya hukum Islam melarang perbuatan yang melangar normanorma kesusilaan. Sehingga dengan mencantumkan larangan isi perjanjian kawin melangar hukum Islam, hakekatnya sudah melingkupi larangan melanggar undang-undang dan kesusilaan.

\section{Waktu Pembuatan Perjanjian Kawin}

Waktu untuk pembuatan perjanjian kawin telah ditentukan secara tegas dalam BW. Pada Pasal 147 disebutkan bahwa setiap perjanjian kawin harus dibuat sebelum perkawinan berlangsung. Ketentuan pasal ini tidak dapat dilepaskan dengan ketentuan Pasal 149 yang menyebutkan bahwa setelah perkawinan berlangsung, perjanjian kawin dengan cara bagaimanapun tidak dapat diubah.
Menurut J. Satrio, ketentuan BW tersebut dimaksudkan untuk memberikan perlindungan terhadap pihak ketiga supaya tidak dihadapkan kepada situasi yang berubah-ubah sehingga dapat merugikan dirinya selaku kreditur. ${ }^{19}$

Sedikit berbeda dengan ketentuan dalam BW, UU Perkawinan menambahkan waktu pembuatan perjanjian kawin pada saat perkawinan dilangsungkan. Jika BW hanya memberikan waktu sebelum perkawinan dilangsungkan, maka UU Perkawinan memberikan peluang membuat perjanjian kawin sebelum dan pada saat perkawinan dilangsungkan. Ketentuan ini dirumuskan pada Pasal 29 ayat (1) UU Perkawinan yang menyebutkan bahwa :

"Pada waktu atau sebelum perkawinan dilangsungkan, kedua belah pihak atas perjanjian bersama dapat mengadakan perjanjian tertulis yang disahkan oleh pegawai pencatat perkawinan setelah mana isinya berlaku juga terhadap pihak ketiga sepanjang pihak ketiga tersangkut."

Sedangkan dalam Kompilasi Hukum Islam, ketentuan waktu pembuatan perjanjian kawin memiliki kesamaan dengan waktu yang ditentukan dalam UU Perkawinan, yaitu harus dibuat sebelum atau pada saat perkawinan dilangsungkan. Pada Pasal 47 ayat (1) Kompilasi Hukum Islam disebutkan bahwa

19 J. Satrio, Hukum Harta Perkawinan, Citra Aditya Bhakti, Bandung 1993, hlm. 28. 
"Pada waktu atau sebelum perkawinan dilangsungkan, kedua calon mempelai dapat membuat perjanjian tertulis yang disahkan pegawai pencatat nikah mengenai kedudukan harta dalam perkawinan."

Dari uraian di atas dapat dikemukakan bahwa secara umum waktu pembuatan perjanjian ditentukan sebelum atau pada saat perkawinan dilangsungkan. Sehingga tidak ada peluang bagi pasangan suami istri untuk membuat perjanjian kawin setelah perkawinan dilangsungkan. Namun demikian dalam praktik di Indonesia, banyak pasangan suami istri membuat perjanjian kawin setelah perkawinan dilangsungkan. Dengan berbagai alasan dan kepentingan, pasangan suami istri mengajukan permohonan kepada pengadilan untuk mendapatkan penetapan. Hal ini dapat dilihat pada penetapan Pengadilan Negeri Jakarta Timur No. 207/Pdt.P/2005/PN.Jkt.Tmr. yang diajukan oleh pasangan suami istri Syam Lal Uttam dan Kavita Uttam, dan Penetapan Pengadilan Negeri Jakarta Timur No. 459/Pdt.P/2007/PN.Jkt.Tmr. yang diajukan oleh pasangan suami istri Dubagunta Ramesh dan Selvia Setiawan.

Permohonan penetapan yang diajukan oleh pasangan suami istri dalam kedua penetapan tersebut pada pokoknya meminta agar pengadilan menetapkan halhal sebagai berikut :
1. Menyatakan bahwa sejak tanggal penetapan telah terjadi pemisahan harta para pemohon selaku pasangan suami istri.

2. Menyatakan bahwa pemisahan harta pasangan para pemohon juga terhadap harta-harta lainnya yang akan timbul dikemudian hari tetap terpisah satu dengan yang lainnya, sehingga tidak lagi berstatus harta bersama.

3. Memerintahkan kepada Pejabat/Pegawai Kantor Dinas Kependudukan dan Catatan Sipil untuk mencatatkan Pemisahan Harta Bersama pada catatan pinggir Akta Perkawinan para pemohon.

Atas permohonan para pemohon tersebut, Pengadilan Negeri Jakarta Timur mengabulkan dengan menerbitkan penetapan. Selanjutnya berdasarkan penetapan pengadilan tersebut, pasangan suami istri selaku pemohon penetapan membuat perjanjian kawin di hadapan notaris.

\section{Perubahan dan Pencabutan Perjanjian}

\section{Kawin}

Mengenai perubahan perjanjian kawin, BW memberikan peluang untuk dilakukan oleh calon mempelai. Hanya saja peluang untuk merubah perjanjian kawin dibatasi waktunya sebelum perkawinan dilangsungkan. Pada Pasal 148 BW disebutkan bahwa :

"Segala perubahan dalam
perjanjian, yang sedianya pun boleh 
diadakan sebelum perkawinan, tak dapat diselenggarakan dengan cara lain, melainkan dengan akta dan dalam bentuk sama, seperti akta perjanjian itu dulu pun dibuatnya. Selama daripada itu, tiada suatu perubahan pun boleh berlaku, jika penyelenggaraannya tidak dihadiri dan tidak disetujui oleh segala mereka, yang dulu telah menghadiri dan menyetujui perjanjian."

Ketentuan Pasal 148 BW di atas memberikan kesempatan kepada calon mempelai untuk melakukan perubahan perjanjian kawin yang telah dibuat. Akan tetapi perubahan tersebut hanya dapat dilakukan sebelum perkawinan dilangsungkan. Selain itu harus dibuat dalam bentuk yang sama, yaitu dalam bentuk akta notaris, dan harus pula disepakati oleh kedua calon mempelai. Waktu untuk melakukan perubahan perjanjian kawin yang hanya ditetukan sebelum perkawinan dilangsungkan juga dipertegas dalam Pasal 149 BW yang menyebutkan bahwa: "Setelah perkawinan berlangsung, perjanjian perkawinan dengan cara bagaimanapun, tak boleh diubah."

Berdasarkan ketentuan BW tersebut, maka pasangan suami istri tidak diberikan peluang untuk melakukan perubahan perjanjian kawin setelah perkawinan dilangsungkan. Hal ini berbeda dengan ketentuan yang ada dalam UU Perkawinan. Pada Pasal 29 ayat (4) UU Perkawinan disebutkan bahwa :
"Selama perkawinan berlangsung perjanjian tersebut tidak dapat diubah, kecuali bila dari kedua belah pihak ada perjanjian untuk mengubah dan perubahan tidak merugikan pihak ketiga."

Ketentuan Pasal 29 ayat (4) UU

Perkawinan tersebut memberikan peluang kepada pasangan suami istri untuk mengubah perjanjian kawin yang telah dibuat selama dalam ikatan perkawinan, dengan syarat harus disepakati oleh kedua belah pihak, dan perubahan yang dilakukan tidak merugikan pihak ketiga. Dengan demikian, UU Perkawinan tidak membatasi waktu untuk melakukan perubahan perjanjian kawin sebagaimana diatur dalam BW. Jika BW membatasi perubahan perjanjian kawin hanya dapat dilakukan sebelum perkawinan dilangsungkan, maka UU Perkawinan membolehkan pasangan suami istri mengubah perjanjian kawin kapan saja selama masih terikat dalam perkawinan. Sedangkan Kompilasi Hukum Islam tidak mengatur soal perubahan perjanjian kawin, akan tetapi menambahkan ketentuan pencabutan perjanjian kawin.

Mengenai pencabutan perjanjian kawin sendiri tidak diatur baik dalam BW maupun dalam UU Perkawinan. Ketentuan pencabutan perjanjian kawin hanya dapat ditemukan dalam Kompilasi Hukum Islam. Pada Pasal 50 ayat (2) Kompilasi Hukum Islam disebutkan bahwa : 
"Perjanjian perkawinan mengenai harta, dapat dicabut atas persetujuan bersama suami istri dan wajib mendaftarkannya di kantor pegawai pencatat nikah tempat perkawinan dilangsungkan."

Syarat untuk melakukan pencabutan perjanjian kawin, selain harus atas persetujuan kedua belah pihak pasangan suami istri, juga tidak boleh merugikan perjanjian yang telah dibuat oleh pasangan suami istri dengan pihak ketiga. ${ }^{20}$ Pencabutan perjanjian kawin juga harus didaftarkan di kantor pegawai pencatat nikah. Sejak pendaftaran pencabutan perjanjian kawin, maka pencabutan tersebut mengikat kepada suami istri. Akan tetapi pencabutan perjanjian kawin tidak lantas mengikat pihak ketiga. Karena pencabutan perjanjian kawin baru akan berlaku mengikat pihak ketiga bilamana pendaftaran pencabutan perjanjian kawin diumumkan oleh pasangan suami istri dalam suatu surat kabar setempat. ${ }^{21}$ Kewajiban untuk mengumumkan pendaftaran pencabutan perjanjian kawin juga menimbulkan konsekuensi hukum tersendiri. Apabila dalam jangka waktu selama enam bulan sejak didaftarkan tidak juga diumumkan di surat kabar, maka pendaftaran pencabutan

\footnotetext{
20 Lihat ketentuan Pasal 50 ayat Kompilasi Hukum Islam.

21 Lihat ketentuan Pasal 50 ayat (3) Kompilasi Hukum Islam.
}

perjanjian kawin dengan sendirinya gugur dan tidak mengikat terhadap pihak ketiga. $^{22}$

\section{Ketentuan Perjanjian Kawin}

\section{Berdasarkan Putusan Mahkamah}

Konstitusi No. 69/PUU-XIII/2015

Pada tanggal 27 Oktober 2016, Mahkamah Konstitusi telah memutus perkara pengujian undang-undang terhadap ketentuan Pasal 29 ayat (1) UU Perkawinan. Putusan Mahkamah Konstitusi No. 69/PUU-XIII/2015 tersebut telah mengubah ketentuan mengenai perjanjian kawin. Jika sebelumnya perjanjian kawin hanya dapat dibuat sebelum dan pada saat perkawinan dilangsungkan, maka Mahkamah Konstitusi menyatakan bahwa perjanjian kawin dapat dibuat oleh pasangan suami istri setelah perkawinan dilangsungkan, atau selama ikatan perkawinan berlangsung.

Permohonan pengujian undangundang tersebut diajukan oleh $\mathrm{Ny}$. Ike Farida, warga negara Indonesia yang menikah dengan seorang laki-laki berkewarganegaraan Jepang.

Perkawinannya sendiri telah dicatatkan di Kantor Urusan Agama Kecamatan Kakasar Kotamdya Jakarta

22 Lihat ketentuan Pasal 50 ayat Kompilasi Hukum Islam. 
Timur, dan telah pula didaftarkan di Kantor Catatan Sipil DKI Jakarta. Pemohon mendalilkan bahwa hak konstitusionalnya telah dirugikan oleh ketentuan Pasal 21 ayat (1), ayat (3), dan Pasal 36 ayat (1) UU No. 5 Tahun 1960 tentang Peraturan Dasar Pokok-Pokok Agraria (selanjutnya disebut UU Agraria), dan Pasal 29 ayat (1), ayat (3), ayat (4), dan Pasal 35 ayat (1) UU No. 1 Tahun 1974 tentang Perkawinan.

Permasalahan yang dialami pemohon bermula ketika ia membeli satu unit rumah susun di Jakarta. Setelah pemohon membayar lunas, pengembang tidak juga menyerahkan unit rumah susun kepada pemohon. Pengembang justru membatalkan jual beli rumah susun tersebut, dan meminta penetapan kepada pengadilan untuk dapat mengembalikan uang pembelian unit rumah susun kepada pemohon secara konsinyasi (consignatie). Dasar yang digunakan pihak pengembang untuk membatalkan kesepakatan jual beli unit rumah susun adalah ketentuan Pasal 36 ayat (1) UU Agraria dan Pasal 35 ayat (1) UU Perkawinan, yang pada pokoknya menentukan bahwa seorang perempuan yang kawin dengan warga negara asing, dan tidak membuat perjanjian kawin dilarang untuk membeli tanah dan/atau bangunan dengan status Hak Guna
Bangunan (HGB). Karena status harta dalam perkawinan menjadi harta bersama.

Mengingat pemohon dan suaminya sebelum perkawinan dilangsungkan tidak membuat perjanjian kawin terhadap harta, maka status harta pemohon dan suaminya dalam perkawinan menjadi harta bersama. Padahal suami pemohon yang berkewarganegaraan asing dilarang memiliki tanah dan/atau bangunan dengan status HGB. Sehingga pemohon juga terkena konsekuensi larangan tersebut. Masalahnya pemohon dan suaminya juga tidak lagi memiliki peluang membuat perjanjian kawin pemisahan harta bersama, karena berdasarkan ketentuan Pasal 29 ayat (1) UU Perkawinan, perjanjian kawin hanya dapat dibuat sebelum atau pada saat perkawinan dilangsungkan. Sebagai warga negara Indonesia, pemohon merasa hak konstitusionalnya dirugikan.

Terhadap permohonan tersebut, Mahkamah Konstitusi mengabulkan sebagian permohonan pemohon, yaitu pada ketentuan Pasal 29 ayat (1), ayat (3), dan ayat (4) UU Perkawinan. Menurut Mahkamah Konstitusi, ketentuan yang ada saat ini hanya mengatur perjanjian perkawinan yang dibuat sebelum atau pada saat perkawinan dilangsungkan, padahal dalam kenyataannya ada fenomena suami istri yang karena alasan tertentu baru merasakan adanya kebutuhan untuk 
membuat perjanjian perkawinan selama dalam ikatan perkawinan. Selama ini sesuai dengan Pasal 29 UU Perkawinan, perjanjian yang demikian itu harus diadakan sebelum perkawinan dilangsungkan dan harus diletakkan dalam suatu akta notaris. Perjanjian perkawinan ini mulai berlaku antara suami dan istri sejak perkawinan dilangsungkan. Isi yang diatur di dalam perkawinan tergantung pada kesepakatan pihak-pihak calon suami istri, asal tidak bertentangan dengan undang-undang, agama, dan kepatutan atau kesusilaan.

Berdasarkan pertimbangan tersebut, Mahkamah Konstitusi berpendapat bahwa frasa "pada waktu atau sebelum perkawinan dilangsungkan" dalam Pasal 29 ayat (1), frasa “...sejak perkawinan dilangsungkan" dalam Pasal 29 ayat (3), dan frasa "selama perkawinan berlangsung" dalam Pasal 29 ayat (4) UU Perkawinan membatasi kebebasan dua orang individu untuk melakukan atau kapan akan melakukan perjanjian, sehingga bertentangan dengan Pasal 28E ayat (2) UUD 1945. Dengan demikian, frasa "pada waktu atau sebelum perkawinan dilangsungkan" dalam Pasal 29 ayat (1), dan frasa "selama perkawinan berlangsung" dalam Pasal 29 ayat (4) UU Perkawinan adalah bertentangan dengan UUD 1945 secara bersyarat sepanjang tidak dimaknai termasuk pula selama dalam ikatan perkawinan.

Berlandaskan pada pertimbangan hukum tersebut, Mahkamah Konstitusi memberikan putusan sebagai berikut $:^{23}$

1. Pasal 29 ayat (1) UU Perkawinan bertentangan dengan UUD 1945 sepanjang tidak dimaknai "Pada waktu, atau sebelum dilangsungkan atau selama dalam ikatan perkawinan kedua belah pihak atas persetujuan bersama dapat mengajukan perjanjian tertulis yang disahkan oleh pegawai pencatat perkawinan atau notaris, setelah mana isinya berlaku juga terhadap pihak ketiga sepanjang pihak ketiga tersangkut.'

2. Pasal 29 ayat (3) UU Perkawinan bertentangan dengan UUD 1945 sepanjang tidak dimaknai "Perjanjian tersebut mulai berlaku sejak perkawinan dilangsungkan, kecuali ditentukan lain dalam perjanjian perkawinan."

3. Pasal 29 ayat (4) UU Perkawinan bertentangan dengan UUD 1945 sepanjang tidak dimaknai "Selama perkawinan berlangsung, perjanjian perkawinan dapat mengenai harta perkawinan atau perjanjian lainnya, tidak dapat diubah atau dicabut, kecuali bila dari kedua belah pihak ada persetujuan untuk mengubah atau mencabut, dan perubahan atau pencabutan itu tidak merugikan pihak ketiga."

${ }^{23}$ Lihat putusan Mahkamah Konstitusi No. 69/PUU-XIII/2015 tanggal 27 Oktober 2016. 
Kedudukan Hukum Perjanjian Kawin

Setelah Adanya Putusan Mahkamah

Konstitusi No. 69/PUU-XIII/2015

Pada dasarnya perubahan ketentuan perjanjian kawin sebelum dan setelah adanya putusan Mahkamah Konstitusi No. 69/PUU-XIII/2015 tanggal 27 Oktober 2016 hanyalah pada waktu pembuatan perjanjian kawin. Jika sebelumnya perjanjian kawin hanya dapat dibuat oleh calon mempelai sebelum dan pada saat perkawinan dilangsungkan, maka sekarang perjanjian kawin tidak hanya dapat dibuat oleh calon mempelai sebelum atau pada saat perkawinan dilangsungkan, tetapi juga dapat dibuat oleh pasangan suami istri setelah perkawinan dilangsungkan, atau selama ikatan perkawinan berlangsung.

Sedangkan mengenai ketentuan perubahan perjanjian kawin, pada hakikatnya sudah diberikan peluang dalam UU Perkawinan. Demikian pula mengenai pencabutan perjanjian kawin juga sudah diatur dalam Kompilasi Hukum Islam. Sementara daya mengikat perjanjian kawin terhadap pihak ketiga, baik ketentuan sebelum maupun setelah adanya putusan Mahkamah Konstitusi tidak mengalami perubahan.

$$
\text { Sebelum adanya putusan }
$$

Mahkamah Konstitusi No. 69/PUUXIII/2015, kedudukan hukum perjanjian kawin yang dibuat oleh pasangan suami istri setelah perkawinan berlangsung terikat pada ketentuan Pasal 29 UU Perkawinan, yaitu tidak sah dan tidak mengikat, kecuali didasarkan pada penetapan pengadilan yang dimohonkan oleh pasangan suami istri sebelum membuat perjanjian kawin. Sehingga tanpa adanya penetapan pengadilan, maka perjanjian kawin yang dibuat selama ikatan perkawinan berlangsung tidak sah dan tidak mengikat. Tetapi setelah adanya putusan Mahkamah Konstitusi No. 69/PUU-XIII/2015, kedudukan perjanjian kawin yang dibuat oleh pasangan suami istri selama ikatan perkawinan berlangsung adalah sah dan berlaku mengikat, baik kepada kedua belah pihak, maupun kepada pihak ketiga sepanjang pihak ketiga tersangkut.

Namun demikian, frasa "...setelah mana isinya berlaku juga terhadap pihak ketiga sepanjang pihak ketiga tersangkut," dihubungkan dengan perjanjian kawin yang dibuat selama ikatan perkawinan berlangsung mengandung ambiguitas. Apalagi jika perkawinan sudah berlangsung lama, dan pasangan suami istri telah membuat bermacam perjanjian dengan pihak ketiga. Sejauh mana kata "tersangkut" dapat mengikat pihak ketiga. Apakah isi perjanjian kawin yang menyangkut pihak ketiga harus disetujui oleh pihak ketiga? Ataukah tidak harus 
disetujui oleh pihak ketiga yang tersangkut? Bagaimana bila isi perjanjian menyepakati bahwa yang harus melaksanakan suatu perjanjian dengan pihak ketiga hanyalah satu pihak saja, baik suami atau istri ? Padahal semula perjanjian dibuat oleh pasangan suami istri dengan pihak ketiga. Tentu permasalahan seperti ini harus menjadi atensi dari pemerintah, agar tidak melahirkan permasalahan baru di masyarakat.

\section{PENUTUP}

Kedudukan hukum perjanjian kawin yang dibuat oleh pasangan suami istri setelah perkawinan berlangsung terikat pada ketentuan Pasal 29 UU Perkawinan, yaitu tidak sah dan tidak mengikat, kecuali didasarkan pada penetapan pengadilan. Tetapi setelah adanya putusan Mahkamah Konstitusi No. 69/PUU-XIII/2015 tanggal 27 Oktober 2016, kedudukan perjanjian kawin yang dibuat oleh pasangan suami istri selama ikatan perkawinan berlangsung adalah sah dan berlaku mengikat, baik kepada kedua belah pihak, maupun kepada pihak ketiga sepanjang pihak ketiga tersangkut.

\section{DAFTAR PUSTAKA}

Buku

Abdurrahman, 1995, Kompilasi Hukum Islam di Indonesia, Akademika Pressindo, Jakarta.
Atiyah, P.S., 1979, The Rise and Fall of Freedom of Contract, Clarendon Press, Oxford.

Bagir Manan, 2003, Teori dan Politik Konstitusi, Faultas Hukum UII, Yogyakarta.

J.J. Bruggink, 1996, Rechsreflecties, alih bahasa Arief Sidharta, Citra Aditya Bakti, Bandung.

J.H. Nieuwenhuis, 1985, Pokok-Pokok Hukum Perikatan, Terjemahan Djasadin Saragih, Universitas Airlangga, Surabaya.

J. Satrio, 1993, Hukum Harta Perkawinan, Citra Aditya Bhakti, Bandung.

Mochamad Djais, 2008, Hukum Harta Kekayaan Dalam Perkawinan, Fakultas Hukum Universitas Diponegoro, Semarang.

Moch. Isnaeni, 2016, Hukum Perkawinan Indonesia, Revka Petra Media, Surabaya.

Tan Thong Kie, 2000, Studi Notariat Serba-Serbi Praktek Notaris, Ichtiar Baru van Hoeve, Jakarta.

\section{Jurnal}

A.H. Angelo and E.P. Ellinger, "Unconscionable Contract: A Comparative Study of the Approaches in England, France, Germany, and the United States", Loyola of Los Angeles International \& Comparative Law Review, Vol. 14, January 1992.

Peter Mahmud Marzuki, "Batas-Batas Kebebasan Berkontrak", Yuridika, Vol. 18 No. 3, Mei 2003. 
Taufik El Rahman et.al., "Asas Kebebasan Berkontrak dan Asas Kepribadian Dalam Kontrak-kontrak Outsourcing", Mimbar Hukum, Vol. 23 No. 3, Oktober 2011.

Yati Nurhayati, Perdebatan Antara Metode Normatif dengan Metode Empirik Dalam Penelitian Ilmu Hukum Ditinjau Dari Karakter, Fungsi dan Tujuan Ilmu Hukum, Jurnal Hukum Al Adl, Volume V Nomor 10, Juli-Desember 2013.

\section{Peraturan Perundang-Undangan}

Burgerlijk Wetboek Indonesia, Staatsblad 1847 Nomor 23.

Undang-Undang Republik Indonesia Nomor 1 Tahun 1974, Tentang Perkawinan. Lembaran Negara Republik Indonesia Tahun 1974 Nomor 1. Tambahan Lembaran Negara Republik Indonesia Nomor 3019 .

Peraturan Pemerintah Republik Indonesia Nomor 9 Tahun 1975, Tentang Pelaksanaan Undang-undang Republik Indonesia Nomor 1 Tahun 1974 Tentang Perkawinan.

Kompilasi Hukum Islam.

Instruksi Presiden No. 1 Tahun 1991 tentang Penyebarluasan Kompilasi Hukum Islam.

Keputusan Menteri Agama No. 154 Tahun 1991 tentang Pelaksanaan Instruksi Presiden No. 1 Tahun 1991.

\section{Putusan Mahkamah Konstitusi}

Putusan Mahkamah Konstitusi No. 69/PUU-XIII/2015 tanggal 27

Oktober 2016. 